Article

\title{
Social and Infrastructural Conditioning of Lowering Energy Costs and Improving the Energy Efficiency of Buildings in the Context of the Local Energy Policy
}

\author{
Maria Mrówczyńska ${ }^{1}$, Marta Skiba ${ }^{1, *} \mathbb{1}$, Anna Bazan-Krzywoszańska ${ }^{1}$, Dorota Bazuń ${ }^{2}$ and \\ Mariusz Kwiatkowski ${ }^{2}$ \\ 1 Architecture and Environmental Engineering, Faculty of Civil Engineering, University of Zielona Góra, \\ 65-417 Zielona Góra, Licealna 9, Poland; M.Mrowczynska@ib.uz.zgora.pl (M.M.); \\ A.Bazan@aiu.uz.zgora.pl (A.B.-K.) \\ 2 Psychology and Sociology, Faculty of Education, University of Zielona Góra, 65-417 Zielona Góra, Licealna 9, \\ Poland; D.Bazun@is.uz.zgora.pl (D.B.); M.Kwiatkowski@is.uz.zgora.pl (M.K.) \\ * Correspondence: M.Skiba@aiu.uz.zgora.pl
}

Received: 2 August 2018; Accepted: 28 August 2018; Published: 1 September 2018

\begin{abstract}
The main problem in creating successful efficiency improvement policies is adjusting objectives to local development programs, dependent on public awareness. This article attempts to find a framework for the costs of changing energy policies using neural networks to identify the social-infrastructure conditions. An analysis model is presented of social-infrastructure conditions of energy costs reduction and buildings' efficiency improvement. Data were obtained from standardized interviews with Zielona Góra, Poland inhabitants and the Town Energy Audit documentation. The data were analyzed using an artificial neural network. This allowed the creation of a model to estimate the cost inhabitants will incur if the energy is sourced from RES (Renewable Energy Systems). The city social-infrastructural correlation model enabled diagnosing its fragments that can support decision-making. The paper contributes to the current knowledge demonstrating the possibilities of hierarchical investments, different for various buildings and neighborhoods, that allow for rational public funding. Knowledge of the correlation conditions matters when implementing effective local policy. This work is based on pilot studies not financed by the parties concerned. Multiple themes were intentionally investigated: emission control, reducing energy consumption, renovating buildings, supplying with RES, and energy poverty, to show methods to match the goal (hard) to social conditions (soft), rarely presented in studies.
\end{abstract}

Keywords: local energy policy; energy efficiency of buildings; neural network; social-infrastructural correlation

\section{Introduction}

The demand to adjust urban development policy to the requisites of the European Union (EU) in terms of cutting greenhouse gas emissions is a challenge for Poland, as well as most of the states of Central and Eastern Europe. The requisites call for comprehensive actions that contribute to a decrease in operational demand for heat, electricity, and gaseous fuels. There are several methods for reducing energy consumption. One of them is raising prices, which may become, for some households, the driving force for modernization and the search for savings. However, considering diverse situation of households in Poland, some already have problems with paying for energy [1,2]. Drastically reducing expenses through savings diminishes their quality of life and can increase energy poverty and its impact on health [3]. Other methods of reducing the burning of fossil fuels include upgrading buildings 
and energy-saving activities of the residents and their self-awareness. The use of renewable sources energy is also essential [4].

Every city can shape the support programs for its residents within the general local government activities. A city, as a unit of local government, may participate in multiple international programs financed by the EU; it can use color-labelled certificates, or provide a framework for its residents' activities. The question is how the programs should be designed and what criteria should be considered to ensure their efficacy. The article concerns the underlying activities for a city program to increase energy efficiency.

A city with existing buildings of various standards, inhabited by a diverse population, $\mathrm{n}$ was adopted as the unit of reference in this paper. The city is divided into 50 fragments regarding the dominant urban structure, living standard, heating, and social structure. We attempted, within those parts, to estimate the potential for change, because not all building upgrading activities to reduce energy and heat demand and their use optimization are equally expensive and effective. In addition, the optimization should differ for various buildings, types of heating, and the location (city part). We assumed that it is impossible to accept any criteria or identical proposals for actions for the whole city. Hence, we addressed the detailed research question: how to set, with properly implemented targeted local policy, an effective task hierarchy without significantly increasing the cost of residence, which would result in fuel poverty.

\subsection{Fuel Poverty in Poland}

Fuel poverty is usually attributed to the interaction between low income, energy inefficiency, and energy prices. Three types of instruments are used in Poland to prevent fuel poverty:

1. Social policy: housing, energy, targeted benefits, electricity allowance, and installation of prepaid counters.

2. Indirectly influence fuel poverty through changes in attitudes and awareness: a nationwide advisory support system for the public sector, housing and companies in terms of energy efficiency and renewable energy sources, promotion and energy efficiency education programs [5].

A number of countries are atetmping to fight fuel poverty. Legislators, agencies, state agencies, media, and energy suppliers are fighting this phenomenon with various support programs [6]. In Italy, according to Fabbri, a strategy for solving the problem of energy poverty includes measures to reduce energy prices. The AEEG, the Italian Regulatory Authority for Electricity Gas and Water, introduced a Help for the Poor Tariff, which depends on family income and energy prices [7]. In other countries, assistance means financial support, but also user education in terms of optimal energy consumption. The level of support depends upon a financial capability and the situation of households.

However, there are also important social determinants of energy use, such as awareness and willingness to change [8]. It is much harder and more expensive to implement significant energy savings in existing buildings, although it is usually possible to specify a range of actions that are both energy efficient and cost effective, as stated by Asadi et al. [9]. The scope and severity of energy poverty in Vermont, U.S. were described by Teller-Elsberg et al. [10]. They indicated that energy users do not find the price itself important, but what matters is the amount of the energy bill and its relationship to their income [11]. This means that the financial burden of households with lower income is heavier, even with reduced energy consumption, which has a clear impact on both the energy availability and energy justice [10].

There are different types of support programs in Europe, including the "Warm Front" in the U.K., giving the opportunity to improve the energy efficiency of buildings while searching for savings and improving the health of inhabitants [12]. In Poland, household incomes are often insufficient for heating in winter, which especially concerns single people or people living in buildings that do not meet the basic requirements in terms of energy efficiency, who lack awareness for energy saving. In Zielona Góra, Polan, this especially applies to housing in older towns, where a great solution would 
be using urban heating (produced in CHP_Combined Heat and Power), as its price is determined quite freely by the city authorities. The price threshold of this "junk" energy can be one of the elements of the urban program for energy poverty reduction.

\subsection{Increasing Energy Efficiency}

Social determinants of energy use, especially the financial capabilities of households, should be considered in any strategy for increasing energy efficiency. It is also important to consider public awareness and willingness to change [13]. This requires a responsible urban policy in terms of energy and financial support for some households, whereas for others economic, incentives only would be appropriate. These activities are based on the long-term prospects of the electricity demand in the country. This apparent gap in knowledge was presented by Webb et al. in the first comprehensive review and empirical analysis of plans and investments for sustainable municipal energy in three cities in the U.K. [14].

Energy consumption depends on many factors, such as climate, building design, materials, technologies, energy carriers, applied ways of heating, and tightness of bulkheads, but also on national and local policies [15]. The use of buildings, their condition, the standard of housing, and the local climate are also important [16].

In both the design of new buildings and in modernizing existing buildings, it is essential that the solution and the measures taken are justified and properly chosen. It is possible to find a single design solution that optimizes the weighted sum of the criteria. Gero et al. [17] were among the first who offered a multiple correspondence analysis (MCA) for use in the building design process in order to examine the compromises between the thermal characteristics of a building and other criteria, such as investment cost and storage area. Touloupaki and Theodosiou also applied Multi-Objective Optimization Algorithms to similar issues [18]. The approach to assess modernization scenarios on the basis of a survey of residents began with the EPIQR (Energy Performance, Indoor air Quality, Retrofit) methodology. It identifies the most appropriate modernization action along with a preliminary cost estimation, regarding issues of energy quality and internal environmental quality $[19,20]$. However, examples of optimization in the literature relate to individual buildings and not programs for entire city districts with similar buildings and population structure characteristics.

\subsection{Planning Research}

We set several objectives. First, we aimed to outline the social and infrastructural conditions of lowering energy costs and improving the energy efficiency of buildings in existing neighborhoods using Zielona Góra as an example. This part also includes presenting a model of research on the inhabitants' readiness to use renewable energy sources, as well as to incur the cost of upgrading residential buildings in order to limit energy and heat consumption.

The second objective was to develop a tool that would enable diagnosis considering the above conditions on the basis of limited data, using neural networks, and to find a limit for raising energy prices considering the cost of a poverty reduction program.

Thirdly, we wanted to determine if it is easier to shape an effective urban policy that considers infrastructure and social factors on the basis of a diagnosis, which is the result of such research procedure. Some of the programs financed from the EU structural resources that could be attractive to city residents regard the production and use of energy from renewable sources. The modernization of buildings can be carried out with the application of renewable energy technologies. These technologies, during the energy production, reduce the amount of consumed network energy that is becoming increasingly expensive. Such activity, however, requires greater knowledge and awareness of the inhabitants. Therefore, one of the research questions was: how much are people willing to increase expenditure on energy if it comes from renewable sources?

The analysis of the data obtained from pilot studies using artificial neural networks should be used to predict the distribution of preferences of residents and thermal upgrading potential for 
the whole area of Zielona Góra (Poland). Neural networks, with some margin of error, provide an opportunity to assess the results, using available, though often incomplete or partial, data to prepare local policy programs targeted for local needs to resolve the problem of fuel poverty. The advantage of this solution is the reduction of cost and time to prepare a diagnosis of the readiness of the inhabitants for a local energy saving policy, modernization measures, and the use of renewable energy sources.

Material and the data for the analysis were obtained from standardized interviews with the inhabitants of Zielona Góra in summer 2016 and 2017. National data on the readiness to use renewable energy sources [21-23] were also used.

There is considerable potential for savings of energy and reducing greenhouse gas emissions in houses and cities in Poland, as well as many countries in Central and Eastern Europe. The scale of the economic effect is the highest for detached buildings (over $70 \%$ of all residential buildings in the country), since the owners themselves independently decide on the condition of the houses and they are not bound to a vote of the majority, as in the case of multi-family buildings. However, properly implemented urban energy policy and targeted support programs, including the ones for the modernization of multi-family buildings (where most city residents live), may allow both improving infrastructure and reducing fuel poverty, which is the focus of the remainder of the paper.

We wanted to examine if it is possible to create a program to support energy efficiency improvement for Zielona Góra, which will cover such a diverse infrastructural, urban, social structure. For this purpose, modeling was conducted with a neural network using partial data (collected in the TEA-Town Energy Audit for Zielona Góra, surveys, statistics, and other to build a model that answers the question and supports decision-making at the local level [24] (Figure 1)).

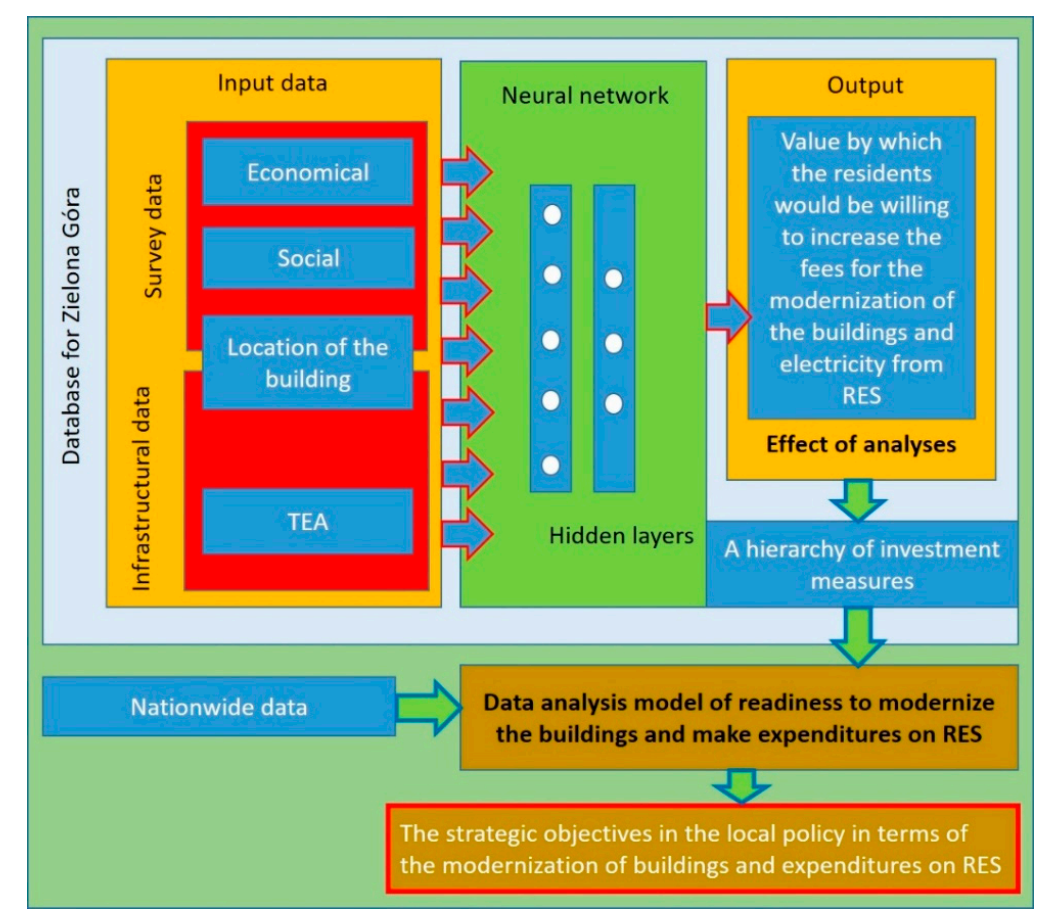

Figure 1. Scheme of modeling the increase in charges for RES energy (Renewable Energy Systems). Model of database links with the aim of increasing energy efficiency and introducing energy from RES to local policy using neural networks.

\section{Results}

Modernization of existing buildings and building new ones in accordance with energy efficient technologies requires appropriate funding. Several factors have an impact on the willingness of the Zielona Góra residents to modernize buildings and apartments. These factors are: 
1. Economic and cognitive factors: knowledge about the upgrading cost, potential energy savings, and the time at which the expenditure will be returned;

2. Ecological awareness: knowledge of the importance of modernization for the environment;

3. Demographic factors: age of residents, education;

4. Economic factors: the level of income per person in the household and an assessment of the financial situation; and

5. Psychological factors: the general willingness (or its lack) to make changes (Figure 2).

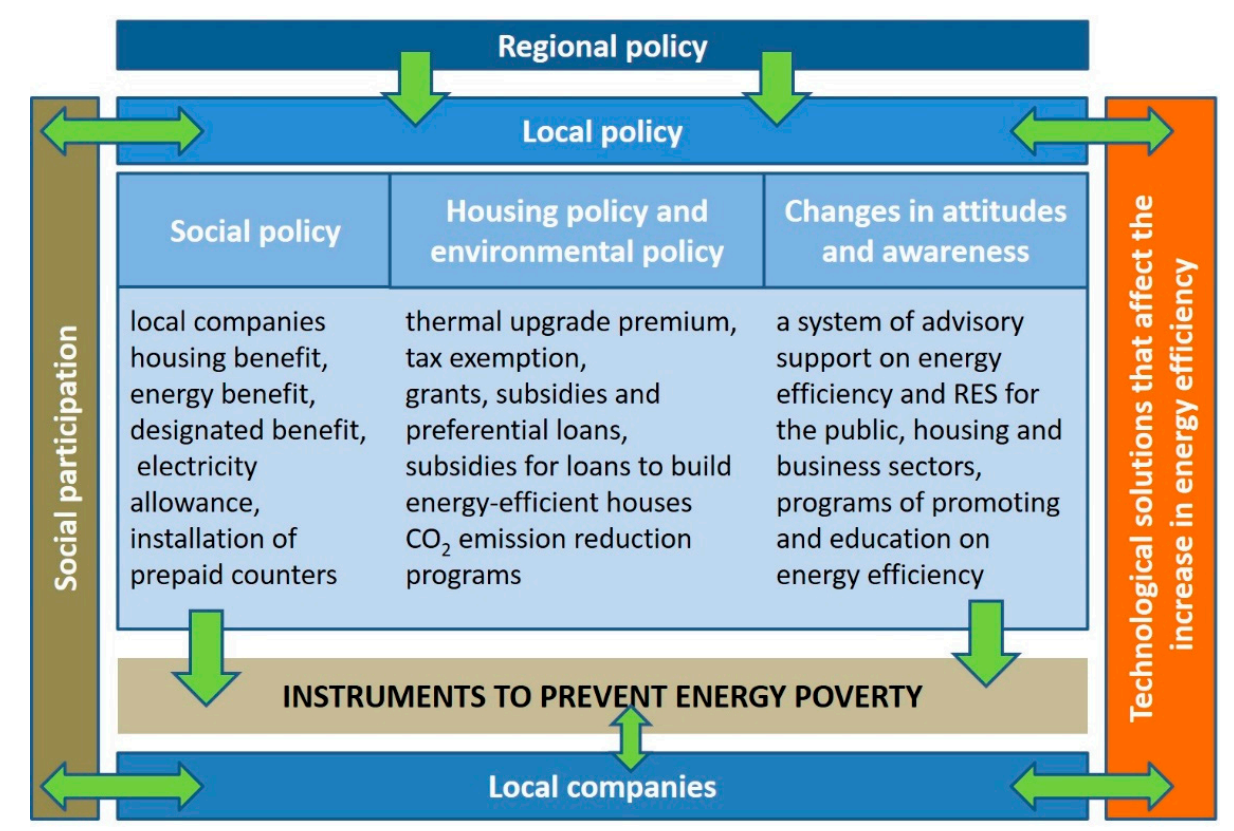

Figure 2. A local policy model, based on social, economic, and technical data to improve the energy efficiency of buildings.

At the level of the general declaration, Zielona Góra inhabitants recognize the fight against environmental pollution as important, or fairly important. However, they seem to be less interested in the issue of incurring any costs due to the use of energy from RES, or modernization of their residential buildings. The respondents who are the owners of the buildings declared greater willingness to invest in changes to energy savings, and this willingness was the highest among owners of detached houses. People having their own property in an apartment building were less interested in potential changes because they feel they can little influence the modernization measures. The majority of respondents declared saving energy by using energy-efficient light bulbs and appliances and by turning off lights when leaving the room. It is difficult to find spare funds for investments in households with low incomes, even if potentially they would save money in the long run.

A challenge for implementing local energy policy is solving issues relating to buildings with high energy intensity indicators. Most often these are historical buildings, protected by conservation legislation, and any changes require the highest expenditures. Most of such properties are located in the city center. The traditional buildings are usually heated using solid fuels. In the central part of Zielona Góra, there are also many properties not owned by the residents; therefore, they are less motivated to modernize them. This is a situation where a potential change in terms of energy efficiency is the most difficult. At the same time, these buildings are inhabited by more people who are already experiencing fuel poverty or are at risk of it. Solving these problems, arising from the overlap of several negative phenomena, requires well-thought-out programs and cooperation of municipal institutions and energy suppliers, with specified solutions accepted by the public. 
Although the age of the respondents was not considered as a research variable, interviews indicated that age does matter when making any investment decision. For the elder residents, a prospect of a fund return on investment in the form of energy savings in several years' time is not convincing. However, when preparing support programs for energy users who are most vulnerable to fuel poverty, it is important to consider their needs and possibilities. In particular, this includes support for elders, both in financial and technical terms, as well as preparing them for changes and their effects (Figures 3 and 4).

\section{CLASS}

\begin{tabular}{|c|c|c|c|c|c|}
\hline \multicolumn{6}{|l|}{ Conventional and corrective measures } \\
\hline Thermal insulation of the external walls of the building and insulating walls in contact with the ground & & & $\mathrm{x}$ & $x$ & $\mathrm{x}$ \\
\hline Thermal insulation of cellar ceilings thermal insulation of ventilated roofs & & & & $\mathrm{x}$ & $\mathrm{x}$ \\
\hline Thermal insulation of repeating thermal bridges (cornices, loggias, balcony slabs) & & & & $x$ & $x$ \\
\hline Replacement of the windows and doors woodwork & & $\mathrm{x}$ & $\mathrm{x}$ & $x$ & $\mathrm{x}$ \\
\hline Shutting of loggias and, in some cases, the demolition of balconies & & $x$ & $\mathrm{x}$ & $\mathrm{x}$ & $\mathrm{x}$ \\
\hline Rinsing and adjustment the central heating along with thermal insulation & $\mathrm{x}$ & $\mathrm{x}$ & $\mathrm{x}$ & $x$ & $\mathrm{x}$ \\
\hline \multicolumn{6}{|l|}{ Remediation actions with the use of renewable energy sources, heat pumps and combined heat and power } \\
\hline Installation of mechanical exhaust system with a heat recovery-recuperator - individual/collective) & & & $\mathrm{x}$ & $\mathrm{x}$ & $\mathrm{x}$ \\
\hline Installation of mechanical exhaust system (instalments, grilles, ventilators) & & & $x$ & $\mathrm{x}$ & $\mathrm{x}$ \\
\hline \multicolumn{6}{|l|}{ Installation of hygroregulated ventilators } \\
\hline Implementation a solar energy system (solar panels, fittings) & & & & $\mathrm{x}$ & $\mathrm{x}$ \\
\hline Implementation of a photovoltaic system (photovoltaic panels, fittings) & & & & $x$ & $\mathrm{x}$ \\
\hline \multicolumn{6}{|l|}{ Grey water recovery system implementation (tanks, fittings, installation of the toilet) } \\
\hline Installation of LED lighting in the corridors, stairwells and in front of the entrance & & & & $x$ & $\mathrm{x}$ \\
\hline Replacement of passenger lifts on energy-saving ones & & & & & $\mathrm{x}$ \\
\hline \multicolumn{6}{|l|}{ Replacement of a central heating and domestic hot water boiler on a biomass boiler } \\
\hline Use of heat pumps & & & & & $x$ \\
\hline Use of combined heat and power system & & & & & $\mathrm{x}$ \\
\hline
\end{tabular}

Figure 3. Activities that the inhabitants of Zielona Góra were asked about and their potential willingness to participate in them and incurring financial expenses.

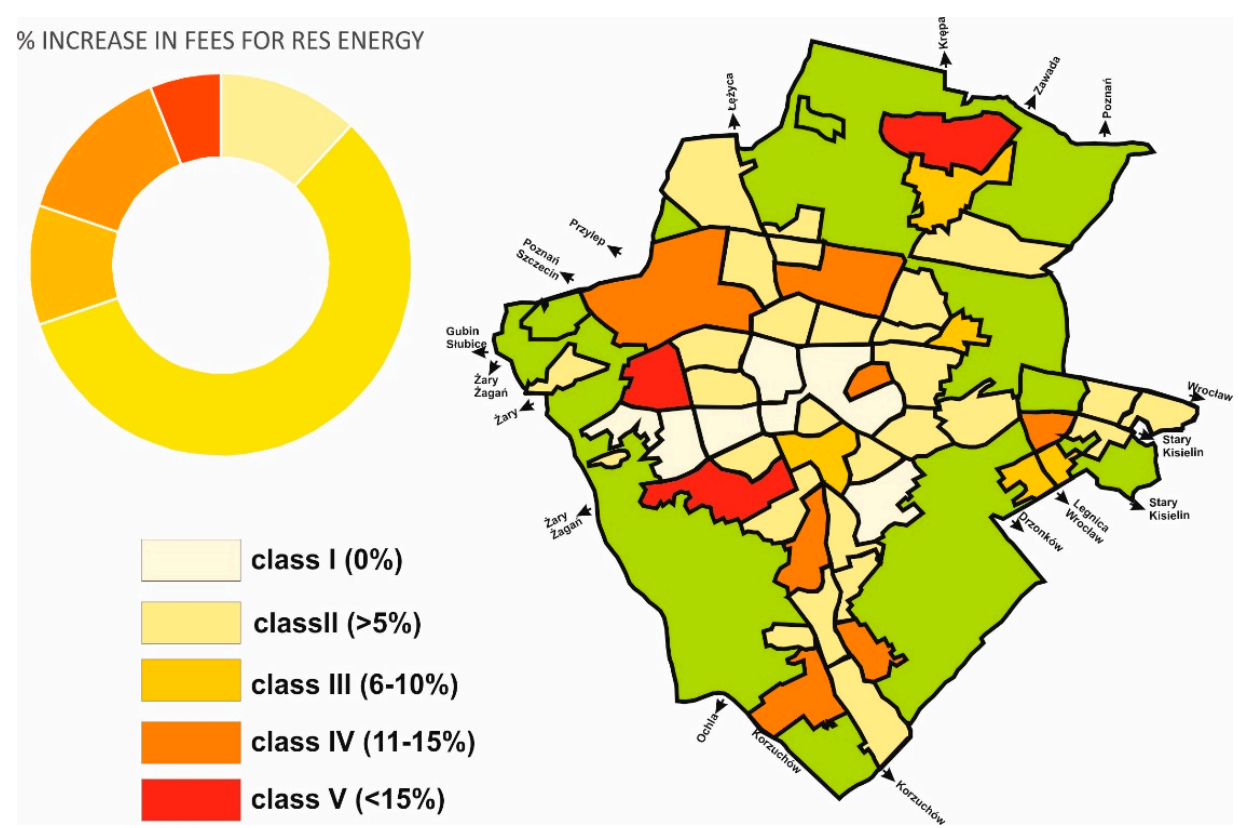

Figure 4. The results of the neural network training in each quarter of Zielona Góra. The percentage of inhabitants ready to pay more for energy from RES in each quarter of the city. 
Another aspect that requires some corrective action is the need to change the awareness of the inhabitants. Every fourth respondent did not feel that the way they function and secure their needs has an impact on the environment. Regarding the results of the survey, it is important to inform residents of the needs and challenges related to environmental protection, as well as educate them in terms of the positive consequences of implementing the mentioned actions, which will bring real savings in the future. A strong argument in this case may be preparing a cost estimate and showing what benefits actions can have on the household budget. Education of consumer habits, to show what action will bring real savings, is also important.

Few inhabitants declared a readiness to assume the role of an energy prosumer. According to the comments of people who took part in the research, a belief in unprofitability of such investment is widespread. The respondents also pointed out formal difficulties and the costs of such investments which, as they claim, will not be recovered for many years. However, they noted the non-economic benefits of such modernization, mentioning mostly the protection of the environment. The results of the standardized interview surveys from the TEA indicate, however, that the low-urbanized outskirts of Zielona Góra could become an RES development area [24-26].

\section{Discussion}

Modeling of energy consumption on an urban scale is essential for the promotion of energy efficiency improvement. Unfortunately, the literature does not provide many good examples or standardized methods for delivering effective town energy planning. In particular, there is lack of appropriate frameworks or systems that provide effective and fair reviews of energy consumption in a developed area on the district-city scale. No examples of research, estimation, or prediction-modelling for urban areas and cities of Eastern Europe were found in the literature.

The work of Webb et al. was based on the analysis of three cities in the United Kingdom; they proposed a model for the multilevel management of city innovations compatible with the principles of sustainable development for coordinated local, regional, and national activities. They concluded that there is a need to equip municipalities and regions with the statutory rights to plan and develop energy efficiency, combined with access to long-term, affordable, and/or financial guarantees [14].

Miu et al. assessed three policies-variable local tax, land tax with a variable stamp duty, and green mortgage-proposed to replace the current large program of modernization in the United Kingdom, known as The Energy Company Obligation (ECO) [27]. They also demonstrated the need for a modernization policy that overcomes the key barriers to the modernization sector, while maintaining profitability for clients, funding organizations, and dealing effectively with the issues of emission reduction in the U.K. and energy poverty.

The Warm Front approach, as described by Sovacool, in terms of the fight against energy poverty, promotes solutions for other energy analysts, planners, and policy makers. It demonstrates the financial benefits of investing in energy efficiency and fast cost-effective energy efficiency programs. "A variety of household energy efficiency measures are the cheapest and best investments society can make if they want" [12].

Models for forecasting energy demand can be compared to the economic model, which considers the size of the gross domestic product (GDP), the population, industry development, and the costs associated with environmental protection [14]. Long-term trends in electricity demand in the country are the basis for shaping the local energy policy. At the local level, the demand for energy is also predicted, depending on how energy is provided to the building, heating, and cooling equipment, focusing on factors such as climate, technical condition of a building, its physical properties, and standard of the appliances with which it is fitted. Energy suppliers are increasingly building predicting models, using, for example, artificial neural networks. It is rare, however, to use a simulation of energy use that supports optimization of management of cities [28]. 


\section{Research and Methods}

\subsection{Research Date}

Material and the data for analysis used in the article were obtained from the Town Energy Audit for Zielona Góra [24], results of the survey carried out with representatives of households in Zielona Góra in 2016 and 2017, and results of the national survey of the expectations and preferences of Polish citizens in terms of energy policy [21-23].

\subsubsection{Town Energy Audit for Zielona Góra}

In this paper, research on construction was used that was done for the city of Zielona Góra, located in the western part of Poland (51 $56^{\prime} 23^{\prime \prime} \mathrm{N}$ and $15^{\circ} 30^{\prime} 18^{\prime \prime} \mathrm{E}$ ). The data for Zielona Góra included the size of the average usable floor area of an apartment, which is $61.5 \mathrm{~m}^{2}$ in Zielona Góra (average in Poland $62.5 \mathrm{~m}^{2}$ ); the size of the average usable area per person, which is $24.6 \mathrm{~m}^{2}$ (average in Poland $24 \mathrm{~m}^{2}$ ); and constantly increasing number of residential buildings and apartments, a steady increase in the size of the usable area of apartments, and the quality and standard of living.

Zielona Góra is characterized by a diverse structure of buildings. The old town is characterized by a compact, frontage development with residential and commercial-residential buildings built using traditional technology. Coal heating equipment is still used within this structure. Single-family and multifamily buildings from the 1950s to the 1970s are located in the city center. Fuel gas is the predominant heat source. Technology of implementation and the quality of materials make the buildings very energy-intensive, often non-insulated, and usually heated by the users with the cheapest energy sources, which are still solid fuels. The old town and the city center are surrounded by a ring of housing estates with multi-family buildings constructed at various periods from the 1950s to the present. The estates were built using traditional or industrialized technology. Detached, semi-detached, and terraced houses, built using traditional technology, are characteristic mainly for the suburbs [24].

The a of research focused on the urban areas of Zielona Góra, designated on the basis of distinctive residential buildings. The city was divided into 50 districts, differentiated in terms of building function, construction technology, and technical condition, assumed in the established model [29,30].

One of the most favorable times to improve the energy efficiency of buildings is during modernization [30]. The most common savings are achieved by reducing the demand on the building usable energy for heating and ventilation. This is possible by reducing heat loss-transmittance through the building envelope, elimination of thermal bridges, such as around the window and door woodwork, balcony slabs thermal insulation, ventilation-and by increasing the heat gains by solar radiation, the use of heat recovery from exhaust air, and outside air preheating.

The results shown in the TEA audit allowed estimating expenses incurred for modernization in order to reduce the energy consumption of buildings with different functions. The calculation for the settlements built in 1993-2008 using high-rise technology presented a necessary expenditure to modernize buildings to obtain a final energy consumption of $75 \mathrm{kWh} / \mathrm{m}^{2} /$ year, which will be required as of 1 January 2021, in accordance with the construction and technical regulations for collective housing (Technical Conditions Act). The cost of reducing the demands for thermal energy of a building to $75 \mathrm{kWh} / \mathrm{m}^{2} /$ year was calculated on the basis of the energy audits. Calculated refurbishing investment effort in accordance with the cost estimates was about one-fifth $\left(750.4 \mathrm{PLN} / \mathrm{m}^{2}\right)$ of the price per $\mathrm{m}^{2}$ of a new apartment sold in 2016 in Zielona Góra, and circa $4100 \mathrm{PLN} / \mathrm{m}^{2}$ in accordance with the law of consuming no more than $75 \mathrm{kWh} / \mathrm{m}^{2} /$ year. Refurbishment cost seems to be so large that, without public acceptance, refurbishment would be impossible to achieve [30].

\subsubsection{Questionnaire Surveys with Representatives of Households in Zielona Góra}

In 2016, pilot surveys were conducted and then repeated in 2017. The study focused on the willingness of the inhabitants of Zielona Góra to pay greater attention to the environment and reduce energy consumption, which is connected with temporary inconveniences during the modernization 
work and long-term expenses and increase in rent to cover the investment cost. The research sample was selected in a purposeful way: those respondents whose households were situated in particular zones specified in the Town Energy Audit [24] were selected. A total of 53 standardized interviews were carried out. To gain more crosscutting results, data from nationwide, representative studies were also used [21-23]. The data were developed with the use of artificial neural networks; therefore, the approximation of the acceptance of increased charges for electricity from RES by the inhabitants was possible at any point in the research area. Notes and digressions of the respondents and interviewers concerning the matter of the questionnaire were also recorded.

The questionnaire included questions about:

1. Occupied property (type and age of the building, rights to the property, area, number of residents, type and date of making a thermal insulation, window for thermal insulation, kind of heating);

2. Importance of the environmental pollution issues in the local scale, that is, readiness to incur increased costs in case of the use of RES;

3. Willingness for changes and investments in order to increase energy and heat savings; and

4. Assessment of the financial situation made by respondents themselves.

Willingness to change was an important element of the research (Figure 4). Figure 3 lists the activities that the inhabitants of Zielona Góra were asked about and their potential willingness to participate in them and incurring financial expenses. The results of national surveys on the possible support of Polish citizens of ecology in the energy industry were also used. The study was carried out by direct interviews conducted on a representative sample of adult residents of Poland (992 respondents) [21-23].

As mentioned before, some of the data were modeled using neural networks. Description of the procedure is presented below.

\subsection{Neural Networks as a Modeling Tool}

Modeling issues related to energy efficiency with artificial intelligence is becoming increasingly common due to the development and availability of modern technologies and the speed of processing information. Neural networks are used for the analysis of energy intensity of buildings [31,32], quantitative assessment of the technological solutions in the process of upgrading buildings [13], cost estimates of completed construction investments [33], and many other aspects of the construction and maintenance of buildings [34]. Typically, neural networks are used to model issues for individual buildings or groups of buildings with the same characteristics. In this article, we decided to use modeling with artificial intelligence for the whole city, divided into smaller units (quarters) depending on several characteristics: age of buildings, technologies, and the dominant construction method. Notably, the data input to the network included information not only about the inhabited buildings, but also information related to the issue of pollution and environmental protection, readiness to change, investment to increase energy and heat savings, and the assessment of the financial situation of the respondents. This approach reduced the knowledge gap concerning the citizens' readiness to incur the financial expenses related to the use of RES energy. A description of the tools and procedures is presented below (Figure 5). 


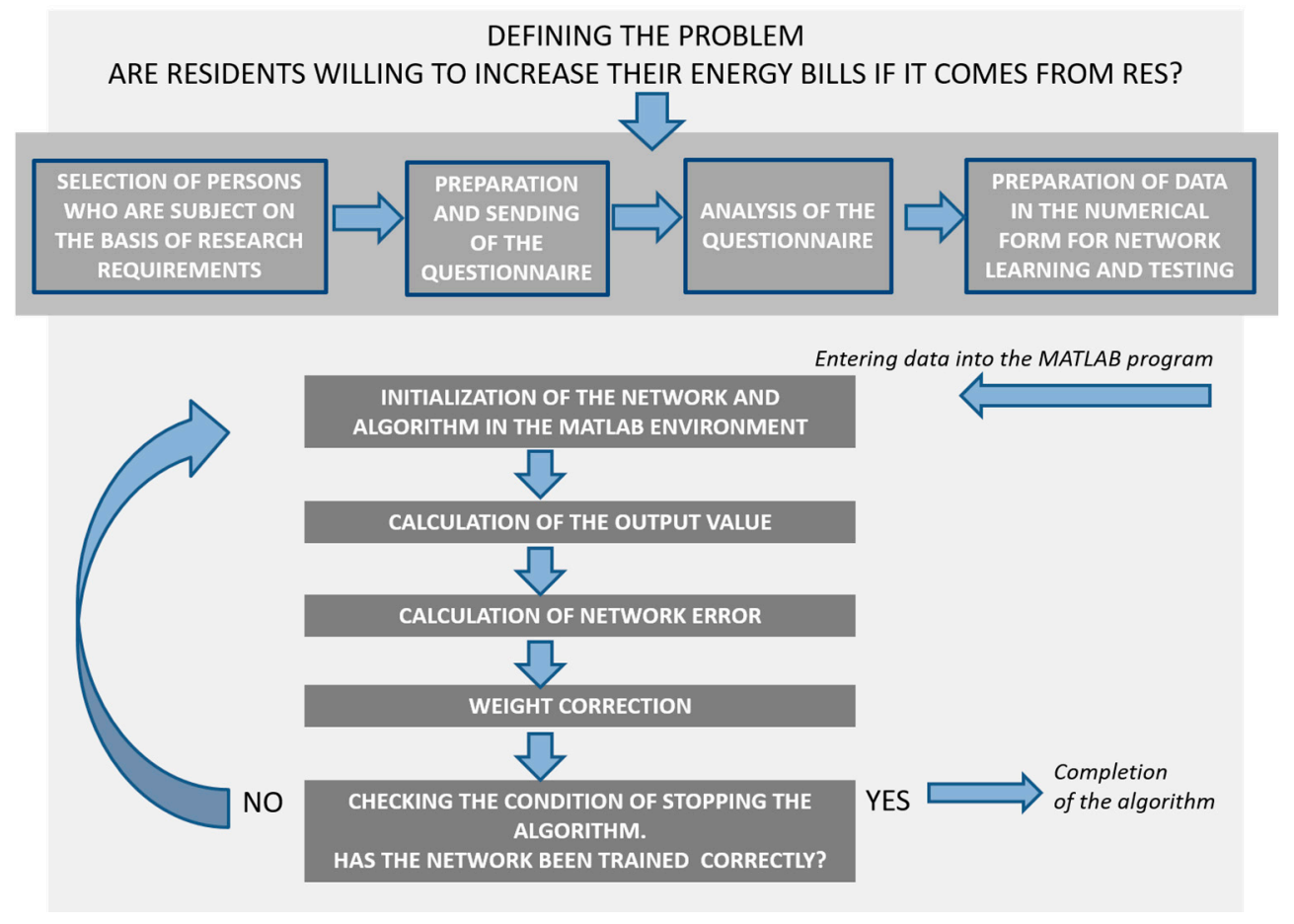

Figure 5. A neural-network-based model of linking the database with the objective to increase in energy efficiency and introduction of RES and local policy directions.

The term artificial neural network is understood as a mathematical algorithm that mimic the actions of biological neural networks that can solve problems they are facing, including technical problems. In addition to mathematical algorithms, there are physical implementations of artificial neural networks (e.g., the first Rosenblatt network, projects in VLSI-Very Large Scale Integration technology), which, however, are rare. The implementations of neural networks are mostly programs and computing algorithms running on classic machines. Hence, neural networks are systems used to process information that learn the relationship between input and output.

Sigmoidal multi-layer artificial neural networks, due to their non-linear nature, are a sophisticated modeling technique included among the methods of computational intelligence (Figure 6). Artificial neural networks allow obtaining beneficial results in practical applications, such as approximation, interpolation, recognition, and classification of patterns, compression, prediction, and many more [6]. A neural network in these and other applications is a universal approximation system able to accomplish a function of non-linear multiple variables, as noted by Nałęcz [35]:

$$
y=f(x)
$$

where the input vector and the vector function are implemented in the whole set of uncertainty. For this reason, many implementations of neural networks involve issues of approximation in multi-dimensional spaces. In order to model the possibility and willingness to pay for increased charges for electricity from renewable sources, as declared by the respondents, a multi-layer neural network trained by backpropagation of errors was used. The network, in order to process the data correctly, must be trained, in which the optimal network architecture is determined, including the number of hidden layers and the number of neurons in layers. Through the training process, the transfer function and additional parameters, such as network training factor or the inclination of the transfer function, are selected. Training and testing the network was carried out using a PC and the MATLAB software by MathWorks, in particular using the Neural Network Toolbox (for Deep Learning), developing our own programs in this environment in order to implement the neural network 
activities. It must be noted that the processes of training and testing the network were carried out for various activation functions (bipolar, unipolar, and sigmoidal) for different network architectures and using a variety of gradient optimization methods (steepest descent method, variable metrics method, conjugate gradient method, and Levenberg-Marquardt method). Selected results of training the neural network are summarized in the Table 1.

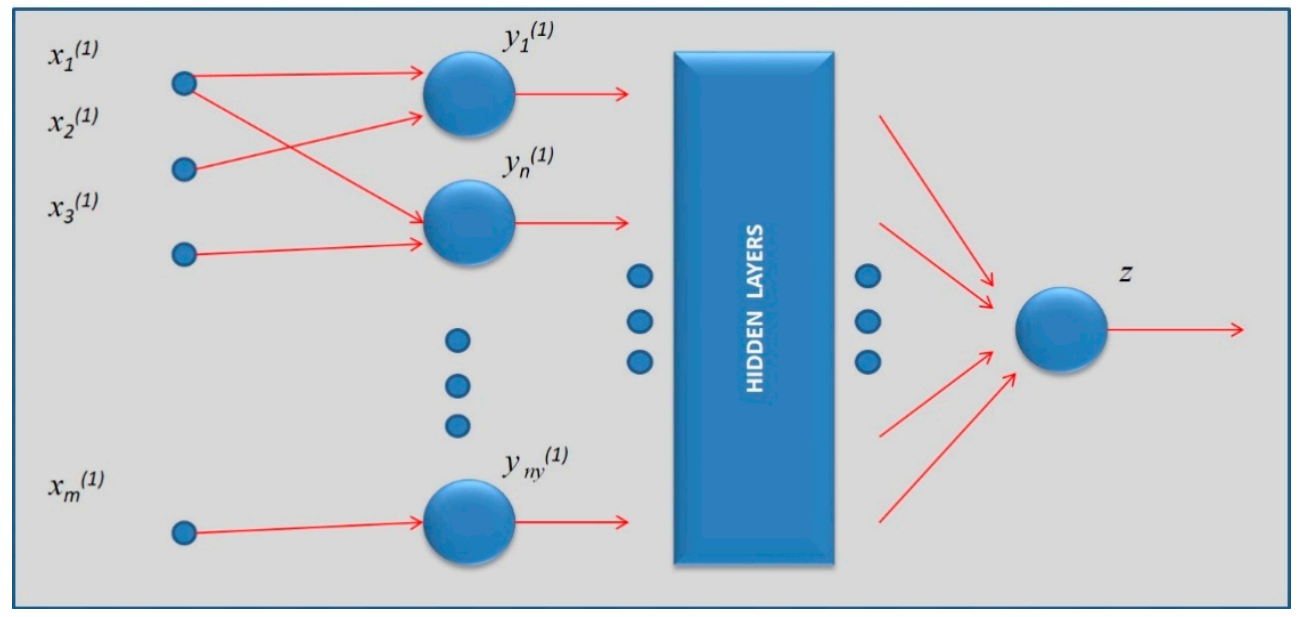

Figure 6. Structure of a feed-forward double-layer network [6].

Table 1. The results of training and testing the neural network in the form of root mean squared erros (RMSE).

\begin{tabular}{|c|c|c|c|c|c|c|}
\hline \multirow{2}{*}{$\begin{array}{c}\text { Network } \\
\text { Architecture }\end{array}$} & \multicolumn{2}{|c|}{ Bipolar Function } & \multicolumn{2}{|c|}{ Unipolar Function } & \multicolumn{2}{|c|}{ Sigmoidal Shape Function } \\
\hline & Training Set & Testing Set & Training Set & Testing Set & Training Set & Testing Set \\
\hline \multicolumn{7}{|c|}{ Steepest Descent Method } \\
\hline 7_2_2_1 & $3.34 \%$ & $3.58 \%$ & $3.32 \%$ & $3.51 \%$ & $3.36 \%$ & $3.45 \%$ \\
\hline 7_3_3_1 & $2.09 \%$ & $2.11 \%$ & $2.10 \%$ & $2.15 \%$ & $2.24 \%$ & $2.56 \%$ \\
\hline 7_4_3_1 & $1.96 \%$ & $2.03 \%$ & $2.01 \%$ & $2.03 \%$ & $2.12 \%$ & $2.25 \%$ \\
\hline 7_5_3_1 & $1.89 \%$ & $2.01 \%$ & $1.95 \%$ & $2.25 \%$ & $1.91 \%$ & $2.00 \%$ \\
\hline 7_5_5_1 & $1.32 \%$ & $2.33 \%$ & $1.45 \%$ & $2.32 \%$ & $1.79 \%$ & $2.58 \%$ \\
\hline \multicolumn{7}{|c|}{ Variable Metrics Method } \\
\hline 7_2_2_1 & $1.38 \%$ & $1.52 \%$ & $1.37 \%$ & $1.54 \%$ & $1.46 \%$ & $1.87 \%$ \\
\hline 7_3_3_1 & $1.22 \%$ & $1.31 \%$ & $1.24 \%$ & $1.32 \%$ & $1.36 \%$ & $1.45 \%$ \\
\hline 7_4_3_1 & $1.01 \%$ & $1.12 \%$ & $0.99 \%$ & $1.07 \%$ & $1.12 \%$ & $1.33 \%$ \\
\hline 7_5_3_1 & $0.85 \%$ & $0.94 \%$ & $0.86 \%$ & $0.92 \%$ & $0.94 \%$ & $1.02 \%$ \\
\hline 7_5_5_1 & $0.75 \%$ & $0.96 \%$ & $0.74 \%$ & $0.92 \%$ & $0.85 \%$ & $1.01 \%$ \\
\hline \multicolumn{7}{|c|}{ Conjugate Gradient Method } \\
\hline 7_2_2_1 & $1.23 \%$ & $1.45 \%$ & $1.21 \%$ & $1.56 \%$ & $1.25 \%$ & $1.72 \%$ \\
\hline 7_3_3_1 & $0.95 \%$ & $1.05 \%$ & $0.94 \%$ & $1.06 \%$ & $0.99 \%$ & $1.22 \%$ \\
\hline 7_4_3_1 & $0.73 \%$ & $0.92 \%$ & $0.74 \%$ & $0.95 \%$ & $0.85 \%$ & $0.99 \%$ \\
\hline 7_5_3_1 & $0.63 \%$ & $0.84 \%$ & $0.64 \%$ & $0.85 \%$ & $0.72 \%$ & $0.89 \%$ \\
\hline 7_5_5_1 & $0.63 \%$ & $0.95 \%$ & $0.64 \%$ & $0.94 \%$ & $0.75 \%$ & $0.91 \%$ \\
\hline \multicolumn{7}{|c|}{ Levenberg-Marquardt Method } \\
\hline 7_2_2_1 & $1.19 \%$ & $1.25 \%$ & $1.20 \%$ & $1.27 \%$ & $1.32 \%$ & $1.58 \%$ \\
\hline 7_3_3_1 & $1.02 \%$ & $1.07 \%$ & $1.03 \%$ & $1.07 \%$ & $1.04 \%$ & $1.19 \%$ \\
\hline 7_4_3_1 & $0.78 \%$ & $0.95 \%$ & $0.77 \%$ & $0.94 \%$ & $0.88 \%$ & $1.02 \%$ \\
\hline 7_5_3_1 & $0.65 \%$ & $0.87 \%$ & $0.65 \%$ & $0.88 \%$ & $0.72 \%$ & $0.93 \%$ \\
\hline 7_5_5_1 & $0.65 \%$ & $0.89 \%$ & $0.66 \%$ & $0.89 \%$ & $0.75 \%$ & $0.94 \%$ \\
\hline
\end{tabular}

In this case, the best learning results were achieved with the use of the multilayer neural network with 7_5_3_1 architecture (two hidden layers, first layer with five neurons, and the second with three 
hidden neurons), trained with a conjugate gradient method, using a bipolar transfer function while training, described with the formula [35]:

$$
y=f(\text { net })=\tanh \left(\lambda_{\text {net }}\right)=\frac{1-\exp (-\lambda \text { net })}{1+\exp (-\lambda \text { net })} \lambda>0
$$

where (net) weighted linear combiner, and $\lambda$ is the slope of the activation function.

The input vector data presented in numerical form included location (address) of the respondent presented as field geo-reference in the form of coordinates $(\mathrm{x}, \mathrm{y})$, age of the building occupied by the respondent, heating zone, area of the property, number of people in the household, and declared monthly income per one family member. The output vector was the value by which a respondent would be able to pay for an increase in the electricity bills if sourced from renewable energies. The coordinates of the input and output vectors were presented in a numerical form and were subject to preliminary data analysis (standardization, a division of the data set on the training set and the test set, which are methods for standardization of the dataset). The training process was perforemed on a training set (70\% of all survey data), and its quality was evaluated on a set of test data, which did was not used for the training process (the remaining $30 \%$ of the survey data). The quality of the training process and testing the network was calculated on the basis of a root mean square error (RMSE), defined by Nałęcz [35] as:

$$
R M S E=\frac{1}{\sqrt{n}} \sqrt{\sum_{i=1}^{n}\left(y_{i}-d_{i}\right)^{2}}
$$

where $n$ is the number of patterns of learning, $d$ is the value of the designated output signal, and $y$ the expected value of the output signal.

As mentioned above, the best results were obtained with the use of the 7_5_3_1 architecture neural network for which the training error RMSE was $0.6 \%$, whereas the test error was $0.8 \%$. The results in the form of the maximum increase in value that the respondent would be willing to pay in terms of electricity bills (the number of willing inhabitants after fees increase in \%), were presented divided into 5 classes, as shown in Figures 3 and 4.

The issue presented here is that the assessment of the willingness to increase household spending for RES energy is complex and lacks the rules to describe it. Instead, we obtained examples of specific behavior and willingness of city residents gathered in the surveys. Therefore, it was necessary to solve the problem with the use of artificial intelligence, in particular the neural networks which, while training on the examples with the known solution, can analyze the problem, draw conclusions, and generalize knowledge. The use of neural networks in our work made it possible to build a model that answers the question about the possibility of increased expenses for RES energy. At the same time, the approach can be replicated and applied to other areas, including other inputs, after a successful training process.

\subsection{Direction for Future Research}

During the pilot study, we found that the question of the willingness to implement a wind power plant system (windmills, fittings) was irrelevant, due to the fact that it simply cannot be implemented in urban areas. A pilot study showed the need to prepare different questionnaires for respondents living in detached or terraced buildings and living in blocks and historic tenements. The feature that also significantly varied in the answers was individual rights to the property. An important part of the next version of the questionnaire would be a question about the need to pay off the mortgage because the conversations conducted while carrying out the questionnaire showed that debt significantly reduced the willingness to invest in energy efficiency.

Although investments in energy efficiency are related to a long-term perspective, it is also important to consider the age of the people responsible for the household in future studies. Developing 
a simple calculator of cost and the potential savings on energy might be useful in more in-depth studies of the willingness to change.

The presented work helps fill the outlined research gap, though it is still incomplete. Our study is based on pilot studies that were not financed by the parties concerned. However, it provides a basis for a the adaptation of future urban programs with variable criteria to the social capabilities of virtually every city population. The authors intentionally attempted multiple themes: from emission control, reducing energy consumption, renovating buildings, and RES supply, to energy poverty. The authors meant to show methods to match the goal (hard) to social conditions (soft), which are often not presented in studies.

Communal and city municipal authorities are the main bodies responsible for monitoring the reduction in energy demand. Due to the need to agree on the process of reaching the values prescribed by the European Commission, it is necessary to monitor energy consumption at all levels of the administrative structure of the country. The improved energy balance of buildings, housing estates, and cities will help Poland maintain its obligations to the EU and Polish legislation. The key objective should be to increase the funding for thermal renovation of single-family buildings and houses in the communities of ownership. It should also be financing a high percentage of comprehensive thermal renovations to reduce final energy consumption, with no financing for low effect investments. Last but not least, Polish legislation should be broadening the thermal renovation support programs as shown in Figure 7). There is a need for public intervention (grants and tax exemptions) to encourage the rational use of energy in households, including supportive (financial) measures generate a lever-jack effect in the form of improvement of existing buildings [28].

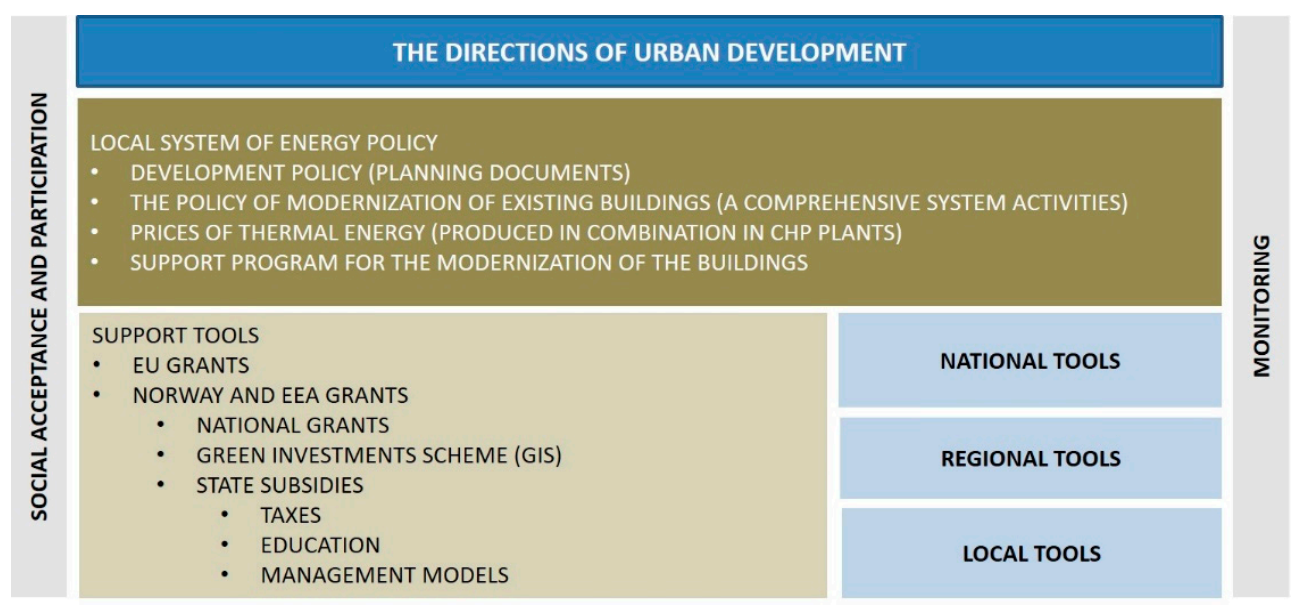

Figure 7. A local policy model, based on social, economic and technical data to improve the energy efficiency of buildings.

Social conditioning of the cost of energy and improving the energy efficiency of buildings apply to two levels: indirectly with households and institutions, via social assistance and relevant city departments, or directly dealing with issues of energy (energy providers).

\section{Conclusions}

One of the challenges in attaining energy efficiency in older cities is creating a system to counteract fuel poverty. This requires reducing energy prices and its availability (regulation) and more intensive use of infrastructure, expressed, among others, by a concentration of areas inhabited by humans [30]. The adopted objectives can be achieved by implementing a responsible urban policy that requires control, direct action, and/or economic incentive. Public institutions, on the one hand, are designed to monitor the situation; on the other hand, they should cooperate in providing support for people 
having problems with access to energy and heat due to economic reasons. A partnership of appropriate entities probides a better chance of effectively preventing fuel poverty.

The city social-infrastructural correlation model enables diagnosing its aspects, which can support decision-making. This paper contributes to the current knowledge by demonstrating the possibilities of hierarchical investments, different for various buildings and neighborhoods, which allow rational public funding. Knowledge of the correlation conditions is important when implementing effective local policy. Despite residents in old multi-family buildings in the city center or its neighborhood being the most at risk of fuel poverty, modernization of the buildings is particularly difficult in the area. It requires comprehensive activities of numerous cooperating institutions: city authorities, social assistance, energy suppliers, and historic buildings conservators. In these places, modernization for RES is difficult. However, measures to prevent fuel poverty and to prepare protective programs for vulnerable users are necessary $[36,37]$.

Currently, comprehensive thermal renovations are usually carried out in multi-family residential buildings with the use of the Thermomodernization Fund, or European funds. Additionally, the owners of single-family buildings have limited support, and at the same time, they are the largest group among the users of modernized buildings. They are the target group that could provide the best opportunity for the development of RES. Programs for economic and technical support for house owners (detached, semi-detached, and terraced) might find the most fertile ground in these case-energy consumers, who are the most interested in lowering costs and increasing the energy efficiency of buildings.

In the case of households, the most important factor, besides having available funding, is seeing opportunities and motivation to change. Such a readiness is higher in people who own the property. Awareness factors were expressed in terms of readiness to bear higher costs, but in return, they gain a sense of greater attention to the environment.

Renovation works ought to be designed in a way to have a chance of returning initial cost during the life of the building (until major renovation) when considering implemented solutions. Energy gain minus the operating cost plus savings resulting from avoiding the cost of inflation should be estimated to have the cost returned within this period [38].

Author Contributions: All authors had an equal contribution to the creation of this article.

Funding: This research received no external funding.

Conflicts of Interest: The authors declare no conflict of interest.

\section{References}

1. Owczarek, D.; Miazga, A. Ubóstwo Energetyczne w Polsce-Definicja i Charakterystyka Społeczna Grupy; Instytut na Rzecz Ekorozwoju: Warszawa, Poland, 2015.

2. Lis, M.; Miazga, A.; Sałach, K. Zróżnicowanie Regionalne Ubóstwa Energetycznego w Polsce; Instytut Badań Strukturalnych: Warszawa, Poland, 2016.

3. Thomson, H.; Snell, C.; Bouzarovski, S. Health, Well-Being and Energy Poverty in Europe: A Comparative Study of 32 European Countries. Int. J. Environ. Res. Public Health 2017, 14, 584. [CrossRef] [PubMed]

4. Kazak, J.; Świąder, M. SOLIS-A Novel Decision Support Tool for the Assessment of Solar Radiation in ArcGIS. Energies 2018, 11, 1-12. [CrossRef]

5. Szpor, A.; Lis, M. Ograniczenie Ubóstwa Energetycznego w Polsce-Od Teorii do Praktyki; Instytut Badań Strukturalnych: Warszawa, Poland, 2016.

6. Stępniak, A.; Tomaszewska, A. Ubóstwo Energetyczne a Efektywność Energetyczna-Analiza Problemu $i$ Rekomendacje; Instytut na Rzecz Ekorozwoju: Warszawa, Poland, 2013; pp. 20-23.

7. Fabbri, K. Building and fuel poverty, an index to measure fuel poverty: An Italian case study. Energy 2015, 89, 244-258. [CrossRef]

8. Kazak, J. The Use of a Decision Support System for Sustainable Urbanization and Thermal Comfort in Adaptation to Climate Change Actions-The Case of the Wrocław Larger Urban Zone (Poland). Sustainability 2018, 10, 1083. [CrossRef] 
9. Asadi, E.; Da Silva, M.; Antunes, C.; Dias, L. A multi-objective optimization model for building retrofit strategies using TRNSYS simulations, GenOpt and MATLAB. Build. Environ. 2012, 56, 370-378. [CrossRef]

10. Teller-Elsberg, J.; Sovacool, B.; Smith, T.; Laine, E. Fuel poverty, excess winter deaths, and energy costs in Vermont: Burdensome for whom? Energy Policy 2016, 90, 81-91. [CrossRef]

11. Lambert, J.G.; Hall, C.A.S.; Balogh, S.; Gupta, A.; Arnold, M. Energy, EROI and quality of life. Energy Policy 2014, 64, 153-167. [CrossRef]

12. Sovacool, B. Fuel poverty, affordability, and energy justice in England: Policy insights from the Warm Front Program. Energy 2015, 93, 361-371. [CrossRef]

13. Asadi, E.; da Silva, M.; Antunes, C.; Dias, L.; Glicksman, L. Multi-objective optimization for building retrofit: A model usinggenetic algorithm and artificial neural network and an application. Energy Build. 2014, 81, 444-456. [CrossRef]

14. Webb, J.; Hawkey, D.; Tingey, M. Governing cities for sustainable energy: The UK case. Cities 2016, 54, $28-35$. [CrossRef]

15. Gorbacheva, N.; Sovacool, B. Pain without gain? Reviewing the risks and rewards of investing in Russian coal-fired electricity. Appl. Energy 2015, 154, 970-986. [CrossRef]

16. Ringel, M.; Schlomann, B.; Krail, M.; Rohde, C. Towards a green economy in Germany? The role of energy efficiency policies. Appl. Energy 2016, 179, 1293-1303. [CrossRef]

17. Gero, J.S.; Dcruz, N.; Radford, A.D. Energy in context-A multicriteria model for building design. Build. Environ. 1983, 18, 99-107. [CrossRef]

18. Touloupaki, E.; Theodosiou, T. Optimization of Building form to Minimize Energy Consumption through Parametric Modelling. Procedia Envirn. Sci. 2017, 38, 509-514. [CrossRef]

19. Flourentzou, F.; Roulet, C.A. Elaboration of retrofit scenarios. Energy Build. 2002, 34, 185-192. [CrossRef]

20. Jaggs, M.; Palmer, J. Energy performance indoor environmental quality retrofit-A European diagnosis and decision making method for building refur-bishment. Energy Build. 2000, 31, 97-101. [CrossRef]

21. CBOS. Polacy o Przyszłości Energetycznej Kraju; CBOS: Warszawa, Poland, 2016.

22. CBOS. Ekologia w Energetyce-Deklaracje i Postawy; CBOS: Warszawa, Poland, 2016.

23. CBOS. Polacy o Oszczędzaniu Energii i Energetyce Obywatelskiej; CBOS: Warszawa, Poland, 2016.

24. Skiba, M. Energetyczny Audyt Miejski. Miejskie Systemy Predykcji Zużycia Energii. Available online: http:/ /yadda.icm.edu.pl/yadda/element/bwmeta1.element.baztech-article-BTB2-0077-0089/c/ Sobierajewicz_Energetyczny_12_2011.pdf (accessed on 31 August 2018).

25. Kuczyński, T. Innowacyjność Podejmowanych Działań w Obszarze Odnawialnych źródeł Energii; Uniwersytet Zielonogórski, Wydział Inżynierii Lądowej i Środowiska: Zielona Góra, Poland, 2008.

26. Staszczuk, A.; Wojciech, M.; Kuczyński, T. The effect of floor insulation on indoor air temperature and energy consumption of residential buildings in moderate climates. Energy 2017, 138, 139-146. [CrossRef]

27. Miu, L.M.; Wisniewska, N.; Mazur, C.; Hardy, J.; Hawkes, A. A Simple Assessment of Housing Retrofit Policies for the UK: What Should Succeed the Energy Company Obligation? Energies 2018, 11, 2070. [CrossRef]

28. Bazan-Krzywoszańska, A.; Skiba, M.; Mrówczyńska, M.; Sztubecka, M.; Bazuń, D.; Kwiatkowski, M. Green energy in municipal planning documents. E3S Web Conf. 2018, 45, 8. [CrossRef]

29. Mrówczyńska, M. Studium Nad Doborem Metod Inteligencji Numerycznej Do Rozwiązywania Problemów z Geodezji Inżynieryjnej; Oficyna Wydaw Uniwersytetu Zielonogórskiego: Zielona Góra, Poland, 2015; ISBN 9788378421580.

30. Skiba, M.; Mrówczyńska, M.; Bazan-Krzywoszańska, A. Modeling the economic dependence between town development policy and increasing energy effectiveness with neural networks. Case study: The town of Zielona Góra. Appl. Energy 2017, 188, 356-366. [CrossRef]

31. Ascione, F.; Bianco, N.; De Stasio, C.; Mauro, G.; Vanoli, G. Artificial neural networks to predict energy performance and retrofit scenarios for any member of a building category: A novel approach. Energy 2017, 118, 999-1017. [CrossRef]

32. Kumar, R.; Aggarwal, R.; Sharma, J. Energy analysis of a building using artificial neural network: A review. Energy Build. 2013, 65, 352-358. [CrossRef]

33. Juszczyk, M.; Leśniak, A.; Zima, K. ANN Based Approach for Estimation of Construction Costs of Sports Fields. Complexity 2018, 7952434. [CrossRef] 
34. Beccali, M.; Ciulla, G.; Brano, V.; Galatioto, A.; Bonomolo, M. Artificial neural network decision support tool for assessment of the energy performance and the refurbishment actions for the non-residential building stock in Southern Italy. Energy 2017, 137, 1201-1218. [CrossRef]

35. Nałęcz, M. Sieci Neurnowe; Akademicka Oficyna Wydawnicza: Warszawa, Poland, 2016.

36. Lis, M.; Sałach, K.; Święcicka, K. Rozmaitość Przyczyn i Przejawów Ubóstwa Energetycznego; Instytut Badań Strukturalnych: Warszawa, Poland, 2016.

37. Szpor, A. Ubóstwo Energetyczne w Polsce-Temat Zastępczy Czy Realny Problem? Instytut Badań Strukturalnych: Warszawa, Poland, 2016.

38. Żurawski, J. Jakość energetyczna a wartość rynkowa nieruchomości. Izolacje 2011, 1, 22-26.

2018 by the authors. Licensee MDPI, Basel, Switzerland. This article is an open access article distributed under the terms and conditions of the Creative Commons Attribution (CC BY) license (http://creativecommons.org/licenses/by/4.0/). 